\title{
Modelling acute leukemias in mice: clonal evolution and the emergence of leukemic stem cells
}

\author{
Bastien Gerby ${ }^{1,2}$, Trang Hoang $1,2,3,4,5^{*}$ \\ From São Paulo Advanced School of Comparative Oncology \\ Águas de São Pedro, Brazil. 30 September - 6 October 2012
}

The concept of cancer stem cells (CSCs) is based on a hierarchic model of cancer whereby cells within a tumour exhibit distinct biological characteristics and only CSCs are able to grow indefinitely and to maintain the neoplastic process. The molecular and cellular characteristics of CSCs are thought to be due to genetic and epigenetic states reminiscent of those normal stem cells. Precisely, cancer arise from the neoplastic transformation of stem cells or committed-progenitor cells [1] through two types of events. First, normal stem cells can acquire genetic alterations that alter its growth control, increase its resistance to apoptosis and interfere with cell differentiation. Second, non-stem cells can be altered by the oncogenic process to reacquire the self-renewal properties of normal stem cells. In both cases, these characteristics confer a particular resistance to drugs, implying that CSCs are involved in the persistence of tumour cells during treatment and consequently, are responsible of relapses.

The concept of CSCs has come from pioneering studies on acute myeloid leukemia (AML) which have defined a distinct subpopulation of tumour cells, the leukemia initiating cells (LICs), characterized by their capacity to initiate the disease when transplanted into imuno-deficient mice $[2,3]$. A confounding issue in the field has been the equation of CSCs with the cell of origin of acute leukemias. Indeed, these original studies and subsequent work suggested that AML derived from the malignant transformation of hematopoietic stem cells (HSCs) [4,5]. However, growing evidence based on cellular and molecular studies led to the recognition that the cell of origin of AML is a committed progenitor that normally lack any potential for

\footnotetext{
* Correspondence: trang.hoang@umontreal.ca

'Institute of Research in Immunology and Cancer, University of Montréal, Montréal, Québec, Canada H3C 3J7

Full list of author information is available at the end of the article
}

self-renewal [6,7]. This controversy may be reconciled by assuming that AMLs may represent in some cases a stem cell disorder, while in other cases, the reacquisition of stem cell characteristics by a committed progenitor [8].

The situation is different in paediatric acute lymphoblastic leukemia (ALL), where there is evidence that leukemia initiating activity is observed not only in the immature cell population but also in populations corresponding to a range of normal precursor cells $[9,10]$. Precisely, the analysis of leukemic and pre-leukemic stem cell populations in a pair of identical twins indicate that the putative stem cell responsible for initiating and maintaining B-ALL are not a fixed cell identity but evolve both in genotype and phenotype [11]. Comforting this observation, a process of clonal evolution at the level of LIC populations was provided both in B-ALL and T-ALL. Indeed, the molecular investigation of individual LIC helped to establish a complex clonal architecture of individual leukemia, showing that LIC are genetically heterogeneous due to the process of clonal evolution [12-14].

$\mathrm{T}$-acute lymphoblastic leukemia (T-ALL) represents about $15 \%$ of paediatric leukemias. Several studies in these last years have, in part, elucidated the molecular mechanism of T-ALL transformation. Indeed, T-leukemogenesis is a multi-step process characterized by the acquisition of several oncogenic events. Especially, genes encoding the SCL transcription factor and its nuclear partners LMO1 and LMO2 are frequently deregulated in T-ALL. Furthermore, activating mutations of $\mathrm{NOTCH} 1$ are found in more than $50 \%$ of T-ALL cases, and are frequently associated with chromosomal abnormalities in the SCL and/or $L M O 1 / 2$ locus $[15,16]$, implying that these mutational events frequently collaborate during neoplastic transformation of thymocytes. It was originally proposed that the

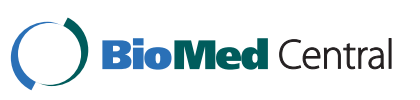

(c) 2013 Gerby and Hoang; licensee BioMed Central Ltd. This is an Open Access article distributed under the terms of the Creative Commons Attribution License (http://creativecommons.org/licenses/by/2.0), which permits unrestricted use, distribution, and reproduction in any medium, provided the original work is properly cited. 
phenotype of the tumor reflects the cell of origin of T-ALL [17]. However, recent studies indicate that fully transformed T-leukemic cells are functionally heterogeneous and may originate from the leukemic transformation of an early T-cell progenitor $[18,19]$. Furthermore, it has been recently shown that the overexpression of the $\mathrm{LMO} 2$ oncogene in the thymus induce the emergence of a preleukemic stem cell (pre-LSC) population [20] but the identification of the cell of origin of T-ALL and the mechanisms by which these oncogenes reprogram normal thymocytes to become T-LIC remain unclear. We took advantage of a transgenic mouse model that closely reproduces paediatric T-ALL to define oncogenic events during the pre-leukemic phase.

We show that SCL-LMO1 inhibit thymocyte differentiation at the double negative to double positive transition, via inhibition of two transcription factors that are essential in the thymus, HEB and E2A [21,22]. Moreover, SCLLMO1 reprograms thymocyte progenitors to confer abnormal self-renewal capacity. The acquisition of stem cell-like properties establishes a pre-leukemic state in thymocytes by causing an expansion of the $\mathrm{CD} 4{ }^{-} \mathrm{CD} 8^{-}$double negative (DN) population of progenitors that actively proliferate under the influence of the pre-TCR and are therefore at risk of acquiring mutations. Strikingly, our data indicate that the pre-TCR favors the acquisition of Notch1 mutations in SCL-LMO1 pre-leukemic stem cells [23]. Finally, SCL, $L M O 1$ and NOTCH1 together induce a polyclonal disease in transgenic mice, which is comparable to that induced by transplantation of a single leukemic stem cell. We therefore conclude that these three oncogenes are sufficient to transform DN thymocytes.

In summary, we show that in T-ALL, the target cell of transformation by the SCL-LMO1 oncogenes are double negative thymocytes that acquire aberrant self-renewal activities but remain non-leukemogenic. Acquisition of activating Notch1 mutations then transforms these thymocyte progenitors into leukemic stem cells [23].

\section{Competing interests}

There are no competing interests in this presentation.

\section{Acknowledgement \\ The work is funded in part by grants from the Canadian Institute of Health Research, The Canadian Cancer Society Research Institute, The Cancer Research Society Inc, the Leukemia Lymphoma Society of Canada and the Ministry of Economic Development, Innovation and Exportation. IRIC infrastructure is supported in part by a group grant from the Fonds de Recherche en Santé du Québec. Bastien Gerby is a post-doctoral fellow of the Cole Foundation.}

\section{Author details}

${ }^{1}$ Institute of Research in Immunology and Cancer, University of Montréal, Montréal, Québec, Canada H3C 3J7. ²Molecular Biology Program, University of Montréal, Montréal, Québec, Canada H3C 3J7. ³ Departments of Medicine, University of Montréal, Montréal, Québec, Canada H3C 3J7. ${ }^{4}$ Department of Pharmacology. University of Montréal, Montréal, Québec, Canada H3C 3J7.
${ }^{5}$ Department of Biochemistry, University of Montréal, Montréal, Québec, Canada $\mathrm{H} 3 \mathrm{C} 3 \mathrm{~J} 7$.

Published: 4 April 2013

\section{References}

1. Reya T, Morrison SJ, Clarke MF, Weissman IL: Stem cells, cancer, and cancer stem cells. Nature 2001, 414(6859):105-11.

2. Lapidot T, Sirard C, Vormoor J, Murdoch B, Hoang T, Caceres-Cortes J, Minden M, Paterson B, Caligiuri MA, Dick JE: A cell initiating human acute myeloid leukaemia after transplantation into SCID mice. Nature 1994, 367(6464):645-648.

3. Bonnet D, Dick JE: Human acute myeloid leukemia is organized as a hierarchy that originates from a primitive hematopoietic cell. Nat Med 1997, 3(7):730-737.

4. Miyamoto T, Weissman IL, Akashi K: AML1/ETO-expressing nonleukemic stem cells in acute myelogenous leukemia with 8;21 chromosomal translocation. Proc Natl Acad Sci USA 2000, 97(13):7521-7526.

5. Bereshchenko O, Mancini E, Moore S, Bilbao D, Månsson R, Luc S, Grover A, Jacobsen SE, Bryder D, Nerlov C: Hematopoietic stem cell expansion precedes the generation of committed myeloid leukemia-initiating cells in C/EBPalpha mutant AML. Cancer Cell 2009, 16(5):390-400.

6. Cozzio A, Passegué E, Ayton PM, Karsunky H, Cleary ML, Weissman IL: Similar MLL-associated leukemias arising from self-renewing stem cells and short-lived myeloid progenitors. Genes Dev 2003, 17(24):3029-3035.

7. Krivtsov AV, Twomey D, Feng Z, Stubbs MC, Wang Y, Faber J, Levine JE, Wang J, Hahn WC, Gilliland DG, Golub TR, Armstrong SA: Transformation from committed progenitor to leukaemia stem cell initiated by MLL-AF9. Nature 2006, 442(7104):818-822.

8. Passegué $\mathrm{E}$, Jamieson $\mathrm{CH}$, Ailles LE, Weissman IL: Normal and leukemic hematopoiesis: are leukemias a stem cell disorder or a reacquisition of stem cell characteristics? Proc Natl Acad Sci USA 2003, 100(Suppl 1):11842-11849.

9. Castor A, Nilsson L, Astrand-Grundström I, Buitenhuis M, Ramirez C, Anderson K, Strömbeck B, Garwicz S, Békássy AN, Schmiegelow K, Lausen B, Hokland P, Lehmann S, Juliusson G, Johansson B, Jacobsen SE: Distinct patterns of hematopoietic stem cell involvement in acute lymphoblastic leukemia. Nat Med 2005, 11(6):630-637.

10. le Viseur C, Hotfilder M, Bomken S, Wilson K, Röttgers S, Schrauder A, Rosemann A, Irving J, Stam RW, Shultz LD, Harbott J, Jürgens H, Schrappe M, Pieters R, Vormoor J: In childhood acute lymphoblastic leukemia, blasts at different tages of immunophenotypic maturation have stem cell properties. Cancer Cell 2008, 14(1):47-58.

11. Hong D, Gupta R, Ancliff P, Atzberger A, Brown J, Soneji S, Green J, Colman S, Piacibello W, Buckle V, Tsuzuki S, Greaves M, Enver T: Initiating and cancer-propagating cells in TEL-AML1-associated childhood leukemia. Science 2008, 319(5861):336-339.

12. Mullighan CG, Phillips LA, Su X, Ma J, Miller CB, Shurtleff SA, Downing JR: Genomic analysis of the clonal origins of relapsed acute lymphoblastic leukemia. Science 2008, 322(5906):1377-1380.

13. Greaves M: Cancer stem cells: back to Darwin? Semin Cancer Biol 2010, 20(2):65-70.

14. Clappier E, Gerby B, Sigaux F, Delord M, Touzri F, Hernandez L, Ballerini P, Baruchel A, Pflumio F, Soulier J: Clonal selection in xenografted human $T$ cell acute lymphoblastic leukemia recapitulates gain of malignancy at relapse. J Exp Med 2011, 208(4):653-661.

15. Weng AP, Ferrando AA, Lee W, Morris JP 4th, Silverman LB, SanchezIrizarry C, Blacklow SC, Look AT, Aster JC: Activating mutations of NOTCH1 in human T cell acute lymphoblastic leukemia. Science 2004, 306(5694):269-271.

16. Tremblay CS, Hoang T, Hoang T: Early $T$ cell differentiation lessons from T-cell acute lymphoblastic leukemia. Prog Mol Biol Trans/ Sci 2010, 92:121-156.

17. Ferrando AA, Neuberg DS, Staunton J, Loh ML, Huard C, Raimondi SC, Behm FG, Pui CH, Downing JR, Gilliland DG, Lander ES, Golub TR, Look AT: Gene expression signatures define novel oncogenic pathways in $T$ cell acute lymphoblastic leukemia. Cancer Cell 2002, 1(1):75-87.

18. Gerby B, Clappier E, Armstrong F, Deswarte C, Calvo J, Poglio S, Soulier J, Boissel N, Leblanc T, Baruchel A, Landman-Parker J, Roméo PH, Ballerini P, Pflumio F: Expression of CD34 and CD7 on human T-cell acute 
lymphoblastic leukemia discriminates functionally heterogeneous cell populations. Leukemia 2011, 25(8):1249-1258.

19. Chiu PP, Jiang H, Dick JE: Leukemia-initiating cells in human

T-lymphoblastic leukemia exhibit glucocorticoid resistance. Blood 2010, 116(24):5268-5279.

20. McCormack MP, Young LF, Vasudevan S, de Graaf CA, Codrington R,

Rabbitts TH, Jane SM, Curtis DJ: The Lmo2 oncogene initiates leukemia in mice by inducing thymocyte self-renewal. Science 2010, 327(5967):879-883.

21. Herblot S, Steff AM, Hugo P, Aplan PD, Hoang T: SCL and LMO1 alter thymocyte differentiation: inhibition of E2A-HEB function and pre-T alpha chain expression. Nat Immunol 2000, 1(2):138-144.

22. Tremblay M, Herblot $\mathrm{S}$, Lecuyer $\mathrm{E}$, Hoang $\mathrm{T}$ : Regulation of $\mathrm{pT}$ alpha gene expression by a dosage of E2A, HEB, and SCL. J Biol Chem 2003, 278(15):12680-12687.

23. Tremblay M, Tremblay CS, Herblot S, Aplan PD, Hébert J, Perreault C, Hoang T: Modeling T-cell acute lymphoblastic leukemia induced by the SCL and LMO1 oncogenes. Genes Dev 2010, 24(11):1093-1105.

doi:10.1186/1753-6561-7-S2-K1

Cite this article as: Gerby and Hoang: Modelling acute leukemias in mice: clonal evolution and the emergence of leukemic stem cells. BMC

Proceedings 2013 7(Suppl 2):K1

\section{Submit your next manuscript to BioMed Central} and take full advantage of:

- Convenient online submission

- Thorough peer review

- No space constraints or color figure charges

- Immediate publication on acceptance

- Inclusion in PubMed, CAS, Scopus and Google Scholar

- Research which is freely available for redistribution

Submit your manuscript at www.biomedcentral.com/submit 